\title{
Analysis of Weight Product (WP) Algorithms in the best Go Car Driver Recommendations at PT. Maranatha Putri Bersaudara
}

\author{
Roni Kurniawan 1 , Agus Perdana Windarto 2 , M. Fauzan ${ }^{3}$, Solikhun ${ }^{4}$, Irfan Sudahri \\ Damanik $^{5}$ \\ 1,2,3,5 STIKOM Tunas Bangsa, Pematangsiantar, North Sumatra, Indonesia \\ ${ }^{4}$ AMIK Tunas Bangsa, Pematangsiantar, North Sumatra, Indonesia \\ ronikurniawan@gmail.com
}

\begin{abstract}
This study aims to rank the best Go Car Driver. The problem arises because of the inaccuracy in giving value to the driver which results in the decision being given incorrectly so that the assessment tends to be subjective. This research was conducted at PT. Maranatha Putri Bersaudara. Sources of data obtained by observing, interviewing. The settlement method used is a decision support system with the Weight Producted method. The assessment criteria used are Performance (C1), Number of orders (C2), Rating (C3), Attitude (C4), Rating (C5) and Appearance (C6) where the alternatives used are 4 samples. The results obtained using the Weighted Product method are Alternative1 and Alternative 4 which are recommended as the best go car driver with the assessment results of 0.0307 and 0.0272 . It is expected that research results can be input to the relevant parties in recommending the best go car driver so as to minimize subjective judgment.
\end{abstract}

Keywords: Decision Support System, Weight Product, Go Car Driver, Ranking.

\section{Introduction}

Transportation is a very important need now. Without the means of transportation, many other activities that can not be done. With the means of transportation, it makes it easier for individuals to move. Any means of transportation from the simplest to the most modern level are now available. The importance of this means of transportation makes the company come up with the idea of establishing a shuttle service business using sophisticated media such as mobile applications. The current online taxi trend has made it easier for people in need. Every community now no longer has to use public transportation such as public transportation (angkot), pedicabs (machines and paddles) or motorcycle taxis. Now there are two online taxis, namely GOJEK and GRAB. Go-car is included in one of the service features of GOJEK. The quality and morale provided by the driver can help the sustainability of a company's progress. To support the spirit of drivers at work, the company applies awards to the best drivers which are carried out periodically. The award given can be in the form of additional incentives or getting rice. PT. Maranatha Putri Bersaudara is one of the companies engaged in the field of construction. This company is located at Jl. Penitentiary, Kp. Lalang, Kec. Sunggal, Deli Serdang Regency, North Sumatra, 20124.

In carrying out company operations, PT. Maranatha Putri Bersaudara give awards to drivers by choosing the best drivers every month. This is intended to increase employee morale at work, especially in providing the best service to customers. The selection of the best drivers is assessed by the assessment team, namely Manager, Assistant Manager and Admin. The best drivers are chosen based on the criteria and sub-criteria of the company. Problems arise when determining who has the right to receive awards. Because basically each assessment criteria has a different bed. the 
inaccuracy of the assessment team in providing ratings to drivers because what is assessed is the subjectiveity of each driver. So the assessment given is still uncertain (fuzzy) [1]. The inaccuracy in giving a value to the driver has an impact on the results of the decision given less precisely so that in the case of the best driver selection there are more subjective properties. The above problems can be corrected by building a Decision Support System (DSS) [2]-[4] by applying a ranking method. Because One of SPK's capabilities supports finding solutions to complex problems [5]-[10]. There are many methods that can be used in the ranking process including the Weight Producted method [11], [12]. This method evaluates several alternatives to a set of attributes or criteria, where each attribute is independent of one another [11]. This is evidenced by several previous studies related to Weight Producted methods conducted [13]. In this research, the Weight Producted method can be applied in the ranking process for giving new customers credit that has the same return value if the method is calculated manually.

\section{Research Methodology}

\subsection{Decision Support System}

Decision support system is an application of information systems aimed at assisting leaders in the decision making process [14]. There are stages that must be carried out in the Decision Making System process, among others: Understanding Phase, Design Phase and Selection Phase [14]-[17].

\subsection{Weighted Product Method}

Weighted Product (WP) is a popular multi-criteria analysis decision that uses multiplication to link attribute ratings, where the rating of each attribute must be raised first with the weight of the attribute in question [11].

\subsection{Design Analysis}

In determining the best go car driver requires the right tools, which use computers as a means that can provide recommendations in the form of accurate and accurate information with a method and systematic calculation. In this case the researchers used the Weighted Product (WP) method. The WP method uses multiplication to attribute attribute ratings where each attribute must be raised first with the attribute weights. This Weighted Product method evaluates several alternatives to a set of attributes or criteria where each attribute is independent of one another.

\section{Results and Discussion}

Here are the results of the analysis using the WP method in recommending the best Go Car driver. The criteria that have been determined include:

a) Criteria

1. Performance $(\mathrm{C} 1)$

2. Number of orders $(\mathrm{C} 2)$

3. Rating (C3)

4. Attitude (C4)

5. Rating (C5)

6. Appearance (C6)

b) Preference Weight (W)

Specified weight values can be converted to crips:

1. Very Important $(\mathrm{SP})=5$

2. Important $(\mathrm{P})=4$

3. Fairly Important $(\mathrm{CP})=3$

4. Less Important $(\mathrm{KP})=2$

5. Not Important $(\mathrm{TP})=1$ 
Determine the preference weights (W)

$\mathrm{C} 1=\mathrm{SP}=5$

$\mathrm{C} 2=\mathrm{P}=4$

$\mathrm{C} 3=\mathrm{CP}=3$

$\mathrm{C} 4=\mathrm{P}=4$

$\mathrm{C} 5=\mathrm{SP}=5$

$\mathrm{C} 6=\mathrm{CP}=3$

$\mathrm{W}=[5,4,3,4,5,3]$

c) Calculating the Criteria Weight Weighting of WP Method:

$$
\begin{aligned}
& \mathrm{W} 1=\frac{5}{5+4+3+4+5+3}=0,21 \\
& \mathrm{~W} 2=\frac{4}{5+4+3+4+5+3}=0,17 \\
& \mathrm{~W} 3=\frac{3}{5+4+3+4+5+3}=0,13 \\
& \mathrm{~W} 4=\frac{4}{5+4+3+4+5+3}=0,17 \\
& \mathrm{~W} 5=\frac{5}{5+4+3+4+5+3}=0,21 \\
& \mathrm{~W} 6=\frac{3}{5+4+3+4+5+3}=0,13
\end{aligned}
$$

Based on the criteria and rating of the suitability of each alternative to each predetermined criterion, then the weighting of each criterion that has been converted to a system number. The criteria used in the study include:

Table 1. Criteria weight value $\left(\mathrm{W}_{\mathrm{j}}\right)$

\begin{tabular}{|c|l|c|}
\hline No & Criteria Name & Weight Value $\left(\mathrm{W}_{\mathrm{j}}\right)$ \\
\hline 1 & Performance $(\mathrm{C} 1)$ & 0,21 \\
\hline 2 & Number of orders $(\mathrm{C} 2)$ & 0,17 \\
\hline 3 & Rating $(\mathrm{C} 3)$ & 0,13 \\
\hline 4 & Attitude $(\mathrm{C} 4)$ & 0,17 \\
\hline 5 & Rating (C5) & 0,21 \\
\hline 6 & Appearance $(\mathrm{C} 6)$ & 0,13 \\
\hline
\end{tabular}

d) Conversion score of criterion value

Following are the results of the conversion of each criterion based on an assessment conducted in recommending the best Go Car driver

1. Performance $(\mathrm{C} 1)$

The table describes the characters determining the best driver where history is issued by the leader which contains a history of the performance results of a go car driver.

Table 2. Performance (C1)

\begin{tabular}{|c|c|c|}
\hline Criteria & Performance & Conversion Value \\
\hline \multirow{3}{*}{ C1 } & $>100 \%$ & 4 \\
\cline { 2 - 3 } & $80-90 \%$ & 3 \\
\cline { 2 - 3 } & $65-79 \%$ & 2 \\
\cline { 2 - 3 } & $<65 \%$ & 1 \\
\hline
\end{tabular}

2. Number of Orders $(\mathrm{C} 2)$

The table explains the conversion of the number of orders that are carried out by each go car driver 
Table 3. Number of Orders (C2)

\begin{tabular}{|c|c|c|}
\hline Criteria & Performance & Conversion Value \\
\hline \multirow{3}{*}{$\mathrm{C} 2$} & 15 & 3 \\
\cline { 2 - 3 } & 10 & 2 \\
\cline { 2 - 3 } & 5 & 1 \\
\hline
\end{tabular}

3. Rating (C3)

This table explains the rating given by the consumer to the go car driver through the "Star" rating which has accumulated over time based on research requirements.

Table 4. Rating (C3)

\begin{tabular}{|c|c|c|}
\hline Criteria & Performance & Conversion Value \\
\hline C3 & Star 5 & 5 \\
\cline { 2 - 3 } & Star 4 & 4 \\
\cline { 2 - 3 } & Star 3 & 3 \\
\cline { 2 - 3 } & Star 2 & 2 \\
\cline { 2 - 3 } & Star 1 & 1 \\
\hline
\end{tabular}

4. Attitude (C4)

This table describes the character of the appointment of the best new driver where the history issued by the leader contains a history of the attitude of a driver going car.

Table 5. Attitude (C4)

\begin{tabular}{|c|l|c|}
\hline Criteria & Performance & Conversion Value \\
\hline \multirow{3}{*}{ C4 } & Good & 3 \\
\cline { 2 - 3 } & Enough & 2 \\
\cline { 2 - 3 } & Less & 1 \\
\hline
\end{tabular}

5. Behavior (C5)

In this table, the best new Driver appointment character is explained where the history issued by the leader contains a history of the behavior of a go car driver.

Table 6. Behavior (C5)

\begin{tabular}{|c|l|c|}
\hline Criteria & Performance & Conversion Value \\
\hline \multirow{3}{*}{ C5 } & Good & 3 \\
\cline { 2 - 3 } & Enough & 2 \\
\cline { 2 - 3 } & Less & 1 \\
\hline
\end{tabular}

6. Appearance (C6)

This table describes the character of the appointment of the best new Driver where the history issued by the leader that contains a history of the appearance of a Go Car driver.

Table 7. Appearance (C6)

\begin{tabular}{|c|l|c|}
\hline Criteria & Performance & Conversion Value \\
\hline \multirow{3}{*}{ C6 } & Good & 3 \\
\cline { 2 - 3 } & Enough & 2 \\
\cline { 2 - 3 } & Less & 1 \\
\hline
\end{tabular}

The data table described in Tables 2 to 7 is an assessment given by the HRD team for the proposed selection of activities to determine the best go car driver. The following is research data provided by the HRD team of the 5 best go car driver candidates in 2018. 
Table 8. Data on potential go car drivers (2018)

\begin{tabular}{|c|c|c|c|c|c|c|c|}
\hline \multirow{2}{*}{ No } & Alternative & \multicolumn{6}{|c|}{ Criteria } \\
\cline { 3 - 7 } & & $\mathrm{C} 1$ & $\mathrm{C} 2$ & $\mathrm{C} 3$ & $\mathrm{C} 4$ & $\mathrm{C} 5$ & C6 \\
\hline 1 & $\mathrm{~A} 01$ & 85 & 10 & Star 3 & Enough & Enough & Good \\
\hline 2 & $\mathrm{~A} 02$ & 75 & 5 & Star 3 & Enough & Less & Good \\
\hline 3 & $\mathrm{~A} 03$ & 60 & 5 & Star 2 & Good & Less & Enough \\
\hline 4 & $\mathrm{~A} 04$ & 80 & 10 & Star 2 & Good & Enough & Less \\
\hline
\end{tabular}

Source: PT. Maranatha Putri Bersaudara

The results of the data that has been converted based on tables 2 to 7 with the data source table 8

Table 9. Conversion data

\begin{tabular}{|c|c|c|c|c|c|c|c|}
\hline \multirow{2}{*}{ No } & \multirow{2}{*}{ Alternative } & \multicolumn{6}{|c|}{ Criteria } \\
\cline { 2 - 8 } & & C1 & C2 & C3 & C4 & C5 & C6 \\
\hline 1 & A01 & 3 & 2 & 3 & 2 & 2 & 3 \\
\hline 2 & A02 & 2 & 1 & 3 & 2 & 1 & 3 \\
\hline 3 & A03 & 1 & 1 & 2 & 3 & 1 & 2 \\
\hline 4 & A04 & 3 & 2 & 2 & 3 & 2 & 1 \\
\hline
\end{tabular}

Decision makers give weight values based on the level of importance of each subcriteria needed. For assessment weights C1, C2, C3, C4, C5, C6 have been determined as discussed in table 1 above. Then the normalization process, where the $S$ vector value sought is the preference value for each alternative. Then the vector $S$ is calculated:

$$
\begin{aligned}
& \mathrm{S} 1=\left(3^{\wedge} 0.21\right)\left(2^{\wedge} 0.17\right)\left(3^{\wedge} 0.13\right)\left(2^{\wedge} 0.17\right)\left(2^{\wedge} 0.21\right)\left(3^{\wedge} 0.13\right)=2.45 \\
& \mathrm{~S} 2=\left(2^{\wedge} 0.21\right)\left(1^{\wedge} 0.17\right)\left(3^{\wedge} 0.13\right)\left(2^{\wedge} 0.17\right)\left(1^{\wedge} 0.21\right)\left(3^{\wedge} 0.13\right)=1,73 \\
& \mathrm{~S} 3=\left(1^{\wedge} 0.21\right)\left(1^{\wedge} 0.17\right)\left(2^{\wedge} 0.13\right)\left(3^{\wedge} 0.17\right)\left(1^{\wedge} 0.21\right)\left(2^{\wedge} 0.13\right)=1,44 \\
& \mathrm{~S} 4=\left(3^{\wedge} 0.21\right)\left(2^{\wedge} 0.17\right)\left(2^{\wedge} 0.13\right)\left(3^{\wedge} 0.17\right)\left(2^{\wedge} 0.21\right)\left(1^{\wedge} 0.13\right)=2,16 \\
& \mathrm{~S} 5=\left(2^{\wedge} 0.21\right)\left(2^{\wedge} 0.17\right)\left(2^{\wedge} 0.13\right)\left(3^{\wedge} 0.17\right)\left(2^{\wedge} 0.21\right)\left(1^{\wedge} 0.13\right)=1,98
\end{aligned}
$$

After calculating the vector $S$, then calculate the value of preference weights $\left(V_{i}\right)$

$$
\begin{array}{lll}
\mathrm{V}_{1}=\frac{2,45}{2,45+1,73+1,44+2,16+1,98} & =0,25 \\
\mathrm{~V}_{2}=\frac{1,73}{2,45+1,73+1,44+2,16+1,98} & & =0,18 \\
\mathrm{~V}_{3}=\frac{1,44}{2,45+1,73+1,44+2,16+1,98} & & =0,15 \\
\mathrm{~V}_{4}=\frac{2,16}{2,45+1,73+1,44+2,16+1,98} & & =0,22 \\
\mathrm{~V}_{5}=\frac{1,98}{2,45+1,73+1,44+2,16+1,98} &
\end{array}
$$

After calculating the value of preference weights (Vi) is done in the WP method, the ranking process can be done by looking at the highest weight value of the 5 alternatives (go car driver). The final results of the WP method calculation can be seen in the following table:

Table 10. Weighted Product Ranking Results

\begin{tabular}{|c|c|c|c|}
\hline \multicolumn{4}{|c|}{ Ranking } \\
\hline Alternative & weight value (Vi) & Ranking & Eligible / Not Eligible \\
\hline A01 & 0,25 & 1 & Eligible \\
\hline A02 & 0,18 & 4 & Not Eligible \\
\hline
\end{tabular}




\begin{tabular}{|c|c|c|c|}
\hline \multicolumn{5}{|c|}{ Ranking } \\
\hline Alternative & weight value (Vi) & Ranking & Eligible / Not Eligible \\
\hline A03 & 0.15 & 5 & Not Eligible \\
\hline A04 & 0,22 & 2 & Eligible \\
\hline A05 & 0,22 & 3 & Eligible \\
\hline
\end{tabular}

Based on table 10, the assessment process has been carried out by looking at the final weighting value from the largest to the smallest. From the calculation results, alternative 1 and alternative 4 (final values $=0.25$ and 0.22 ) are recommended as the best go car driver candidate based on the WP method calculation.

\section{Conclusion}

Based on the results of the implementation and testing of Decision Support Systems in determining the best Go Car Driver at PT. Maranatha Putri Brothers using the Weight Producted method, among others:

a) The system can solve the problem by implementing the Weight Product method.

b) From the system test results, the Weight Product method, produces the same alternatives as the manual calculations performed.

c) From the test results, the Weighted Product method can more quickly process data compared to decision making made in the traditional way.

d) From day six the input assessment criteria include: Performance (C1), Number of orders (C2), Rating (C3), Attitude (C4), Rating (C5) and Appearance (C6) where 4 alternatives are used as an alternative by using the Weighted Product method namely Alternative 1 and Alternative 4 which are recommended as the best go car driver. The results of this calculation are the same as the implementation of the system test made.

\section{References}

[1] D. A. Silitonga, M. Anjelita, and A. P. Windarto, "Fuzzy Inference System Untuk Prediksi Pembelian Bahan Bakar Pertamax Pada SPBU Di Kota Pematangsiantar," Syntax J. Inform., vol. 8, no. 2, pp. 75-83, 2019.

[2] A. P. Windarto and S. S, "Penerapan Algoritma Semut dalam Penentuan Distribusi Jalur Pipa Pengolahan Air Bersih," J. Sist. Inf. Bisnis, vol. 2, pp. 123-132, 2018.

[3] B. Fachri, A. P. Windarto, and I. Parinduri, "Penerapan Backpropagation dan Analisis Sensitivitas pada Prediksi Indikator Terpenting Perusahaan Listrik," J. Edukasi dan Penelit. Inform., vol. 5, no. 2, pp. 202-208, 2019.

[4] I. Parlina, A. Wanto, and A. P. Windarto, "Artificial Neural Network Pada Industri Non Migas Sebagai Langkah Menuju Revolusi Industri 4.0," InfoTekJar J. Nas. Inform. dan Teknol. Jar., vol. 4, no. 1, pp. 155-160, 2019.

[5] D. N. Batubara, A. P. Windarto, and M. R. Raharjo, "Penerapan Promethee II Pada Pemilihan Produk Conditioner Sebagai Upaya Peningkatan Minat Beli Konsumen," CESS (Journal Comput. Eng. Syst. Sci., vol. 4, no. 2, pp. 191-197, 2019.

[6] D. N. Batubara, D. R. S. P, and A. P. Windarto, "Penerapan Metode PROMETHEE II Pada Pemilihan Situs Travel Berdasarkan Konsumen," J. SISFOKOM, vol. 8, no. 1, pp. 46-52, 2019.

[7] D. R. S. P, A. A. Muin, and M. Amin, "Pemilihan Facial Wash Untuk Kulit Wajah Berminyak Dengan Metode Promethee II," CESS (Journal Comput. Eng. Syst. Sci., vol. 4, no. 2, pp. 222-229, 2019.

[8] D. R. Sari, A. P. Windarto, and D. Hartama, "Sistem Pendukung Keputusan untuk Rekomendasi Kelulusan Sidang Skripsi Menggunakan Metode AHP-TOPSIS," J. Teknol. dan Sist. Komput., vol. 6, no. November 2017, pp. 1-6, 2018.

[9] S. M. Dewi and A. P. Windarto, "Analisis Metode Electre Pada Pemilihan Usaha 
Kecil Home Industry Yang Tepat Bagi Mahasiswa,” Sist. J. Sist. Inf., vol. 8, no. 3, pp. 377-385, 2019.

[10] C. Fadlan, A. P. Windarto, and I. S. Damanik, "Penerapan Metode MOORA pada Sistem Pemilihan Bibit Cabai ( Kasus : Desa Bandar Siantar Kecamatan Gunung Malela )," J. Appl. Informatics Comput., vol. 3, no. 2, pp. 42-46, 2019.

[11] A. Jalil and M. M. Ika Purwanti Ningrum, "SPK Pemberian Kredit Menggunakan Metode WP (Weighted Product) Pada BMT Mu'amalah Sejahtera Kendari," semanTIK, vol. 3, no. 1, pp. 173-180, 2017.

[12] A. Setyawan, F. Y. Arini, and I. Akhlis, "Comparative Analysis of Simple Additive Weighting Method and Weighted Product Method to New Employee Recruitment Decision Support System (DSS ) at PT . Warta Media Nusantara," Sci. J. Informatics, vol. 4, no. 1, pp. 34-42, 2017.

[13] M. Mesran, G. Ginting, S. Suginam, and R. Rahim, "Implementation of Elimination and Choice Expressing Reality ( ELECTRE ) Method in Selecting the Best Lecturer ( Case Study STMIK BUDI DARMA )," Int. J. Eng. Res. Technol., vol. 6, no. 2, NaN-2017, pp. 141-144, 2017.

[14] S. R. Ningsih and A. P. Windarto, "Penerapan Metode Promethee II Pada Dosen Penerima Hibah P2M Internal," InfoTekJar (Jurnal Nas. Inform. dan Teknol. Jaringan), vol. 3, no. 1, pp. 20-25, 2018.

[15] A. Putrama and A. P. Windarto, "Analisis dalam menentukan produk bri syariah terbaik berdasarkan dana pihak ketiga menggunakan ahp," CESS (Journal Comput. Eng. Syst. Sci., vol. 3, no. 1, pp. 60-64, 2018.

[16] A. P. Windarto, "Penilaian Prestasi Kerja Karyawan PTPN III Pematangsiantar Dengan Metode Simple Additive Weighting (SAW)," J. Ris. Sist. Inf. Dan Tek. Inform., vol. 2, no. ISSN 2527-5771, pp. 84-95, 2017.

[17] C. Irwana, Z. F. Harahap, and A. P. Windarto, "SPK: Analisa Metode Moora Pada Warga Penerima Bantuan Renovasi Rumah,” JTI, vol. 10, no. 1, pp. 47-54, 2018.

\section{Authors}



$1^{\text {st }}$ Author

\section{Roni Kurniawan}

STIKOM Tunas Bangsa, Pematangsiantar, North Sumatra 